\title{
Kelayakan LKS Berbasis Auditory Intellectually Repetition sebagai Bahan Ajar Alternatif Siswa
}

\author{
Emi Wahyuni Maesarah, Akhmad Sukri, *Herdiyana Fitriani \\ Program Studi Pendidikan Biologi, FSTT, Universitas Pendidikan Mandalika. \\ *Correspondence e-mail: herdiyanafitriani@ikipmataram.ac.id
}

\begin{abstract}
Abstrak: Tujuan dari penelitian ini yaitu untuk mengetahui validitas dan keterbacaan LKS berbasis Auditory Intellectually Repetition (AIR). Penelitian ini merupakan penelitian deskriptif kuantitatif dengan tiga tahap define, desain dan develop. Data penelitian dikumpulkan menggunakan lembar validasi dan angket keterbacaan LKS. Lembar kerja siswa yang telah disusun kemudian divalidasi oleh 3 validator ahli dan dilakukan uji keterbacaan kepada 21 siswa kelas VII. Adapun hasil penelitian pengembangan LKS berbasis Auditory Intellectually Repetition valid digunakan (skor: 3,28 dengan kategori valid), keterbacaan LKS dinyatakan baik (skor: 3,41 dengan kategori baik). Sehingga dapat disimpulkan bahwa LKS berbasis Auditory Intellectually Repetition layak dan dapat digunakan sebagai bahan ajar alternatif siswa.
\end{abstract}

Kata kunci: Lembar Kerja Siswa, Auditory Intellectually Repetition, bahan ajar

\section{The Eligibility of Auditory Intellectually Repetition-Based Worksheets as Alternative Teaching Materials for Students}

\begin{abstract}
The purpose of this study was to determine the validity and legibility of Auditory Intellectually Repetition (AIR) based worksheets. This research is a descriptive quantitative research with three stages i.e define, design and develop. The research data were collected using a validation sheet and a student worksheet readability questionnaire. The student worksheets that had been compiled were then validated by 3 expert validators and readability tests were carried out on 21 class VII students. The results of research on the development of Auditory Intellectually Repetition-based worksheets were valid (score: 3.28 in the valid category), the readability of the worksheets was declared good (score: 3.41 in the good category). So it can be concluded that Auditory Intellectually Repetition-based worksheets was eligible and can be used as alternative teaching materials for students.
\end{abstract}

Keywords: Student Worksheets, Auditory Intellectually Repetition, Teaching materials

How to Cite: Maesarah, E., W., Sukri, A., \& Fitriani, H. (2020). Kelayakan LKS Berbasis Auditory Intellectually Repetition sebagai Bahan Ajar Alternatif Siswa. Empiricism Journal, 1(1), 12-19. doi:https://doi.org/10.36312/ej.v1i1.261

https://doi.org/10.36312/ej.v1i1.261

Copyright@ 2020, Maesarah et al This is an open-access article under the CC-BY-SA License. (c) (i) (2)

\section{PENDAHULUAN}

Salah satu cara untuk menghasilkan SDM yang berkualitas yaitu dengan mengembangkan bahan ajar yang dapat melibatkan siswa dalam proses pembelajaran. Bahan ajar adalah seperangkat sarana atau alat pembelajaran yang berisikan materi pembelajaran, metode, dalam rangka mencapai tujuan yang diharapkan (Widodo dan jasmadi, 2008). Menurut Kusuma, (2016) Pengembangan bahan pembelajaran atau bahan ajar disusun untuk menjadi salah satu referensi yang akan mendukung perkembangan peserta didik agar ada keseimbangan antara kebutuhan jasmani dan rohani. Alat bantu belajar termasuk salah satu unsur dinamis dalam belajar. Kedudukan alat bantu memiliki peranan yang penting karena dapat membantu proses belajar siswa. Ada berbagai jenis bahan ajar yang dapat dikembangkan salah satunya adalah lembar kegiatan siswa.

Lembar kegiatan siswa merupakan lembaran-lembaran yang berisi tugas yang harus dikerjakan oleh peserta didik. LKS merupakan bahan ajar cetak yang berisi materi, ringkasan, dan petunjuk pelaksanaan tugas pembelajaran yang harus dikerjakan oleh peserta didik yang mengacu pada kompetensi yang harus dicapai (Prastowo, 2014). Dengan adanya LKS dapat membantu serta memudahkan bagi guru untuk melaksanakan pembelajaran, selain itu LKS juga dapat mengaktifkan siswa melalui kegiatan-kegiatan yang tersusun di dalamnya. 
Berdasarkan hasil observasi yang dilakukan di SMP Negeri 2 Gerung didapatkan informasi bahwa pembelajaran yang dilakukan telah menggunakan bahan ajar yang berupa buku paket, di mana buku paket yang digunakan adalah buku paket yang disusun dan diterbitkan oleh penerbit yang berasal dari luar pulau Lombok, sehingga materi yang ada di dalamnya membahas mengenai kondisi dan gejala alam di luar pulau lombok dan guru mata pelajaran belum pernah mengembangakan bahan ajar sendiri.

Bahan ajar yang dikembangkan berupa LKS ini berorientasi pada model pembelajaran AIR (Auditory Intellectually Repetition). Pembelajaran seperti ini menganggap bahwa akan efektif apabila memperhatikan tiga hal tersebut. Auditory yang berarti bahwa indera telinga digunakan dalam belajar dengan cara mendengarkan, menyimak, berbicara, persentasi, argumentasi, mengemukakan pendapat dan menanggapi. Intellectually berpikir yang berarti bahwa kemampuan berpikir perlu dilatih melalui latihan bernalar, mencipta, memecahkan masalah, mengkonstruksi dan menerapkan. Repetition yang berarti pengulangan, agar pemahaman lebih mendalam dan luas, siswa perlu dilatih melalui pengerjaan soal, pemberian tugas atau kuis (Suherman, 2003). Hal ini sejalan dengan hasil penelitian dari Burhan, Suherman dan Mirna (2014) yaitu kemampuan pemahaman konsep matematika siswa dengan model pembelajaran AIR lebih baik daripada kemampuan pemahaman konsep matematika siswa dengan pembelajaran konvensional.

LKS berbasis AIR ini menekankan pada belajar dengan menggunakan pendengaran karena tidak mungkin siswa dapat menangkap pembelajaran yang disampaikan guru melalui lisan tanpa melibatkan indera pendengaran, kemudian siswa memikirkan, merenungkan dan memaknai materi tersebut dan membangun makna sendiri. Setelah siswa membangun makna atau pengetahuan sendiri, siswa kemudian akan diberikan pendalaman, perluasan dan pemantapan mengenai materi yang dipelajari. Berdasarkan paparan tersebut dikembangkanlah sebuah bahan ajar yang berupa LKS (Lembar Kerja Siswa) berbasis AIR (Auditory Intellectually Repetition). Melalui pengembangan LKS berbasis AIR ini diharapkan menjadi salah satu bahan ajar alternatif yang dapat digunakan oleh guru dan siswa pada materi pencemaran lingkungan.

\section{METODE}

Jenis penelitian ini adalah penelitian pengembangan (Research \& development) yang menggunakan model 3D yang diadopsi dari model 4D milik Thiagarajan, Semmel \& Semmel (1974) dengan beberapa penyesuaian sehingga sesuai dengan fokus penelitian yang dilakukan. Dimana model 4D ini memiliki empat tahapan yaitu tahap Define (tahap pendefinisian), tahap Design (tahap perancangan), tahap develop (tahap Pengembangan), tahap Disseminate (tahap Penyebaran). Tetapi dalam penelitian ini hanya terbatas sampai tahap ketiga yaitu tahap pengembangan sedangkan tahap penyebaran tidak dilakukan dikarenakan memberikan kesempatan untuk peneliti lain.

Tahapan penelitian meliputi tahap pendefinisian, perancangan, dan pengembangan. Tahap pendefinisisan meliputi analisis kebutuhan yaitu analisis tujuan dan batasan materi. Batasan materi ditentukan dari hasil analisis kompetensi dasar dan indikator yang ada di buku paket guru mata pelajaran IPA terpadu pada pokok bahasan pencemaran lingkungan. Tahap perancangan menurut Degeng (2013) yaitu meliputi tujuan pembelajaran, prosedur pembelajaran serta penilaian. Pada tahapan ini LKS Berbasis AIR disusun disesuaikan dengan model pembelajaran Auditory Intellectually Repetition. Sedangkan pada tahap pengembangan dihasilkan produk berupa LKS Berbasis AIR.

Adapun instrumen yang digunakan dalam penelitian ini adalah lembar validasi ahli dan lembar angket. Teknik pengumpulan data dalam penelitian ini adalah teknik validasi ahli yang diadopsi dari Sukri (2014) untuk mendapatkan data kelayakan LKS. Selain itu juga digunakan teknik angket untuk mendapatkan data keterbacaan LKS yang telah dikembangkan.

Uji keterbacaan LKS berbasis AIR pada materi pencemaran lingkungan dilakukan di SMP Negeri 2 Gerung Kabupaten Lombok Barat. Sedangkan proses pengembangan perangkat pembelajaran dilaksanakan di kampus IKIP Mataram. Uji keterbacaan dilaksanakan pada bulan Agustus 2018. 
Data hasil penelitian yang diperoleh kemudian digolongkan berdasarkan kriteria kelayakan sebagaimana disajikan pada Tabel 1 berikut.

Tabel 1. Kualifikasi Penilaian Kelayakan LKS (Sukri, 2014)

\begin{tabular}{ll} 
Skor & Tingkat Kelayakan \\
\hline $4<S \leq 5$ & Sangat Baik \\
$3<S \leq 4$ & Baik \\
$2<S \leq 3$ & Cukup \\
$1<S \leq 2$ & Kurang \\
$S=1$ & Sangat Kurang
\end{tabular}

Adapun data keterbacaan LKS yang terkumpul dengan menggunakan lembar angket penilaian siswa digolongkan ke dalam kriteria uji keterbacaan yang disajikan pada Tabel 2 berikut.

Tabel 2. Kriteria Uji Keterbacaan LKS (Sukri, 2014)

\begin{tabular}{ll}
\hline Skor & Tingkat Keterbacaan \\
\hline $\mathrm{S}>4$ & Sangat Baik \\
$3<\mathrm{S} \leq 4$ & Baik \\
$2<\mathrm{S} \leq 3$ & Cukup \\
$1<\mathrm{S} \leq 2$ & Kurang \\
$\mathrm{S}=1$ & Sangat Kurang \\
\hline
\end{tabular}

\section{HASIL PENELITIAN DAN PEMBAHASAN}

Hasil dari penelitian pengembangan ini adalah menghasilkan produk berupa LKS yang berorientasi terhadap model pembelajaran AIR. Dengan beberapa tahapan yang dilalui meliputi tahapan pendefinisian, perancangan, dan pengembangan. Adapun komponenkomponen yang dikembangkan yaitu tujuan pembelajaran (meliputi rumusan kompetensi inti, kompetensi dasar, indikator dan tujuan pembelajaran secara khusus). Prosedur pembelajaran meliputi pengorganisasian materi berupa penataan materi pada LKS, penyampaian materi serta pengelolaan pembelajaran. Penilaian dengan cara memberikan soal uji kompetensi berupa soal essay berjumlah 5 soal.

Penelitian pengembangan LKS berbasis Auditory Intellectually Repetition memiliki data hasil pengembangan ada dua yaitu data hasil validasi LKS melibatkan tiga dosen biologi, serta uji keterbacaan yang melibatkan 21 siswa SMP Negeri 2 Gerung kelas VII. Adapun data hasil validasi LKS disajikan pada Tabel 3 di bawah ini.

Tabel 3. Data Kuantitatif Validasi LKS Berbasis AIR

\begin{tabular}{llccc}
\hline No & Validator Ahli & $\begin{array}{c}\text { Nilai } \begin{array}{c}\text { yang } \\
\text { Diperoleh }\end{array} \\
\text { N. }\end{array}$ & Nilai Maksimal & Tingkat Kelayakan \\
\hline 2. & V2 (tampilan) & 3,16 & 5 & Baik \\
3. & V3 (bahasa) & 3,50 & 5 & Baik \\
\hline$\Sigma$ & & 3,50 & 5 & Baik \\
\hline
\end{tabular}

Data di atas didapatkan dari penilaian 3 validator dimana masing-masing validator menilai aspek yang berbeda-beda, aspek isi mendapatkan skor sebesar 19, sehingga nilai yang diperoleh 3,16 dengan kategori baik. Aspek tampilan dengan 10 aspek komponen penilaian dan skor yang didapat yaitu sebesar 35, maka nilai yang diperoleh yaitu 3,50 sehingga LKS dikategorikan baik. Sedangkan aspek bahasa yaitu dengan rincian terdapat 10 komponen penilaian dan skor yang didapatkan yaitu 37, maka nilai yang diperoleh sebesar 3,7 sehingga Iks dikategorikan baik. Dari ketiga validator didapatkan rerata sebesar 3,50 dengan tingkat kelayakan baik.

Data hasil uji keterbacaan didapatkan dari angket keterbacaan yang disebarkan kepada 21 siswa SMP kelas VII. Adapun data hasil uji keterbacaan dalam bentuk diagram pada Gambar 1 di bawah ini. 


\section{Hasil Uji Keterbacaan LKS}
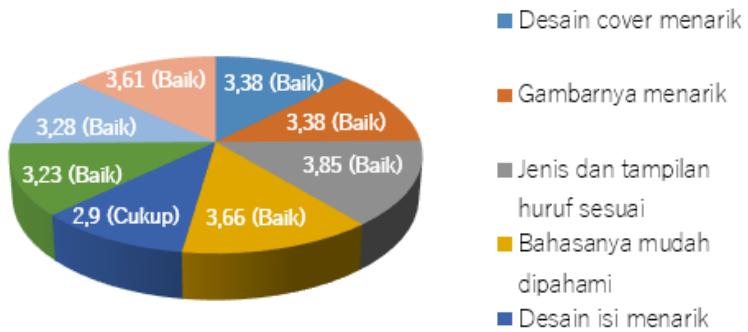

Gambar 1. Diagram Hasil Uji Keterbacaan LKS Terhadap Siswa

Berdasarkan data di atas dari delapan aspek/komponen penilaian, skor tertinggi terdapat pada aspek ketiga mengenai jenis dan tampilan huruf dengan skor rata-rata sebesar 3,85 dengan kategori baik. Kemudian aspek terendah terdapat pada aspek kelima mengenai desain isi menarik dengan skor rata-rata sebesar 2,90 dengan kategori cukup. Adapun aspek komponen yang lain mendapatkan tingkat keterbacaan baik, sehingga rata-rata hasil uji keterbacaan LKS berbasis Auditory Intellectually Repetition yaitu sebesar 3,41 dengan kriteria keterbacaan baik.

Berdasarkan penelitian yang telah dilakukan dihasilkan sebuah produk bahan ajar berupa LKS berbasis Auditoy Intellectually Repetition pada materi pencemaran lingkungan untuk siswa SMP kelas VII. LKS Berbasis AIR ini dapat dijadikan sebagai bahan ajar alternatif siswa dan guru.

Berdasarkan hasil penelitian yang telah dilakukan oleh Hardiyanti, Wahyuni dan Darmawiguna (2013) bahwa model Pembelajaran AIR berpengaruh secara signifikan terhadap hasil belajar siswa kelas $X$ dengan hasil perolehan thitung $=4,612$ sedangkan ttabel $=2,004$. Hal ini sejalan dengan hasil penelitian dari Fitri dan Utomo (2016) yaitu model pembelajaran AIR berpengaruh terhadap kemampuan pemahaman konsep siswa kelas VIII di SMP Pustek Serpong.

Adapun spesifikasi tampilan LKS berbasis AIR yang telah dikembangkan disajikan pada Gambar 2, Gambar 3, Gambar 4, dan Gambar 5.

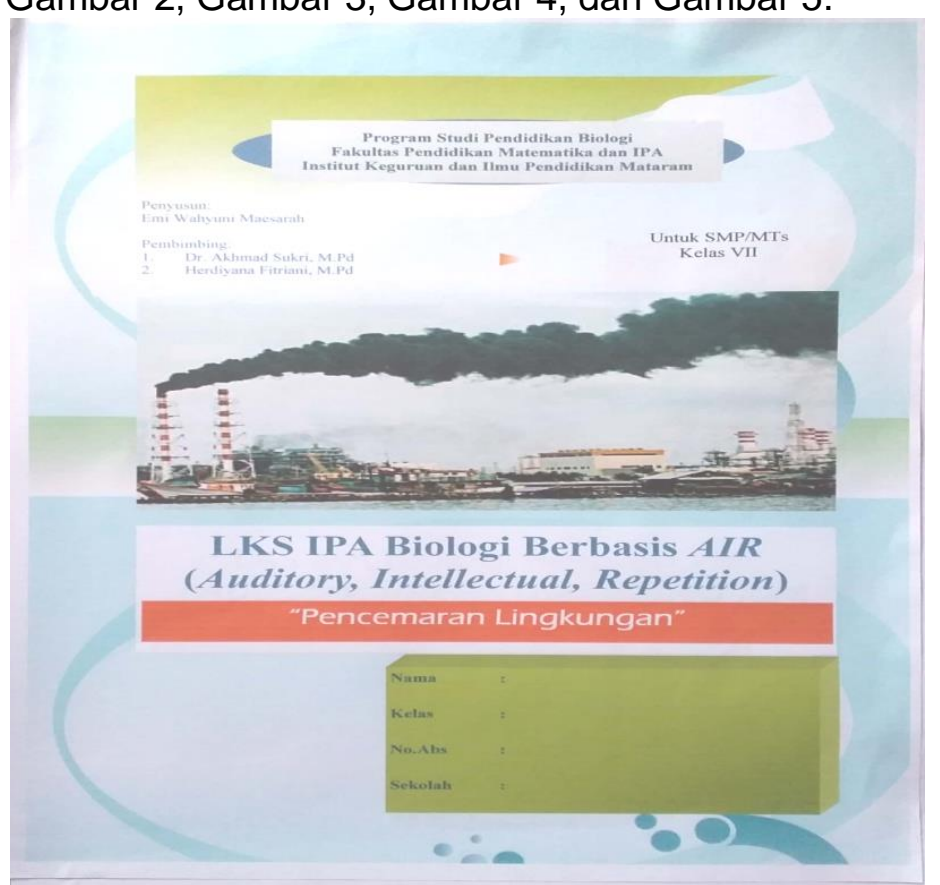

Gambar 2. Tampilan Cover LKS 
Hal| 2

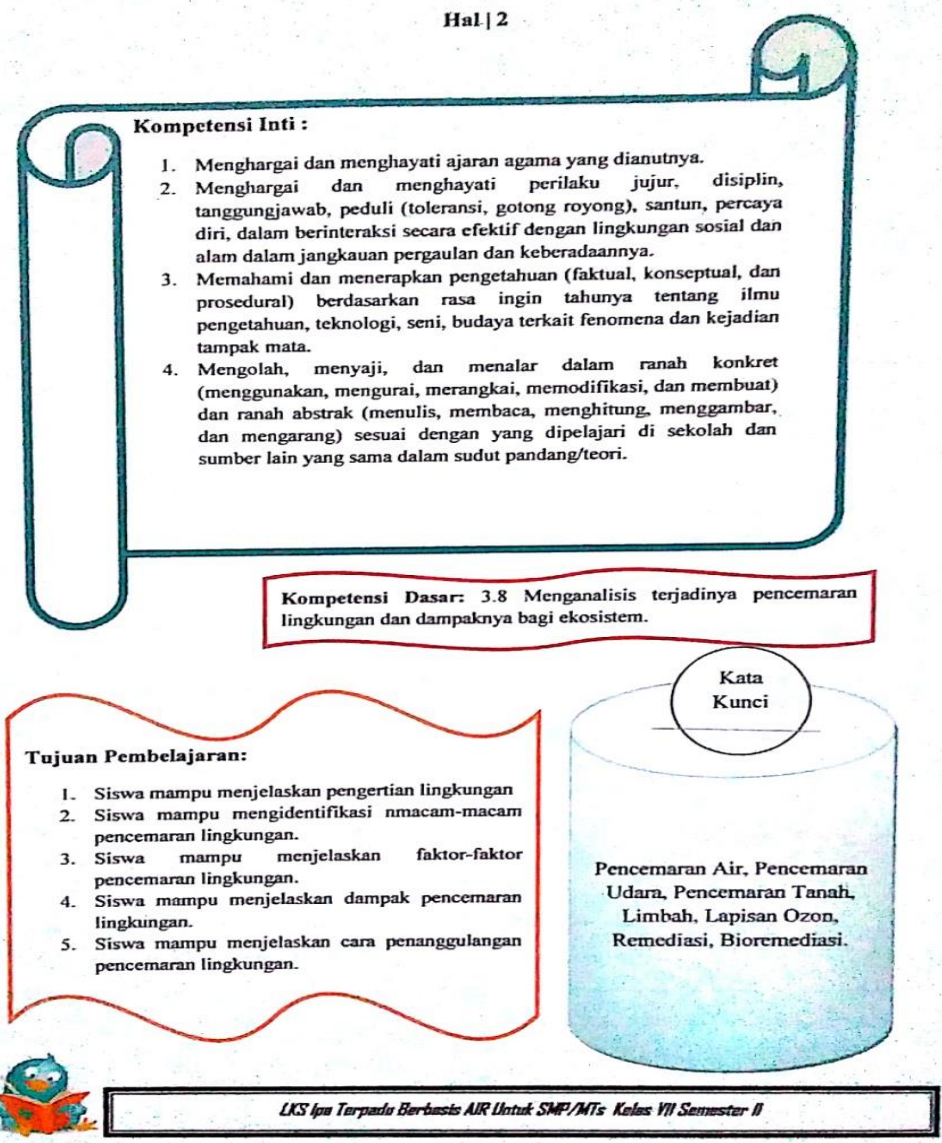

Gambar 3. Tampilan Tujuan Pembelajaran

IIal | 10

d) Munculnya banjir akibat got tersumbat sampah

c) Terjadinya ledakan populasi ganggang dan tumbuhan air (eutrofikasi) serta pendangkalan dasar perairan

3) Cara Penanggulangan Pencemaran Air

Pengolahan limbah bertujuan untuk menetralkan bahan-bahan berbahaya yang terlarut dalam air. Pengolahan air limbah dapat dilakukan sebagai berikut.

a) Pembuatan Kolnm Stabilisasi

Pembuatan Kolam Stabilisasi
Dalam kolam stabilisasi, air limbah diolah secara alamiah Dalam kolam stabilisasi, air limbah diolah secara ala untuk
sebelum dialirkan ke sungai. Hal ini dilakukan guna untal menetralisir zat-zat pencemar.
IPAL (Instalasi Pengolahan Air Limbah)

Refleksi
Diri
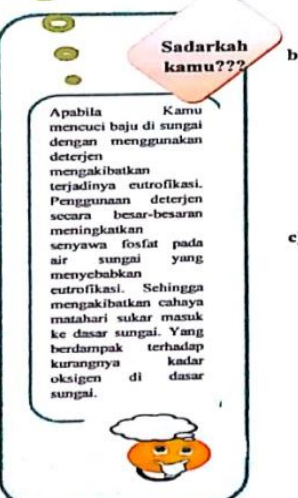

Pengelolaan ini menggunakan alat-alat khusus. Memiliki tiga tahapan yaitu tahap pertama bertujuan untuk memisale bertujuan untuk menstabilisasikan zat organik dalam limbah. Sedangkan tahap terakhir yaitu bertujuan untuk memusnahkan mikroorganisme patogen.

c) Pengelolann Exerata

Yaitu dengan cara menampung dalam jamban dan mengolahnya sehingga tidak mencemari lingkungan.

\section{(3)}

Gambar 4. Tampilan Refleksi Diri LKS 

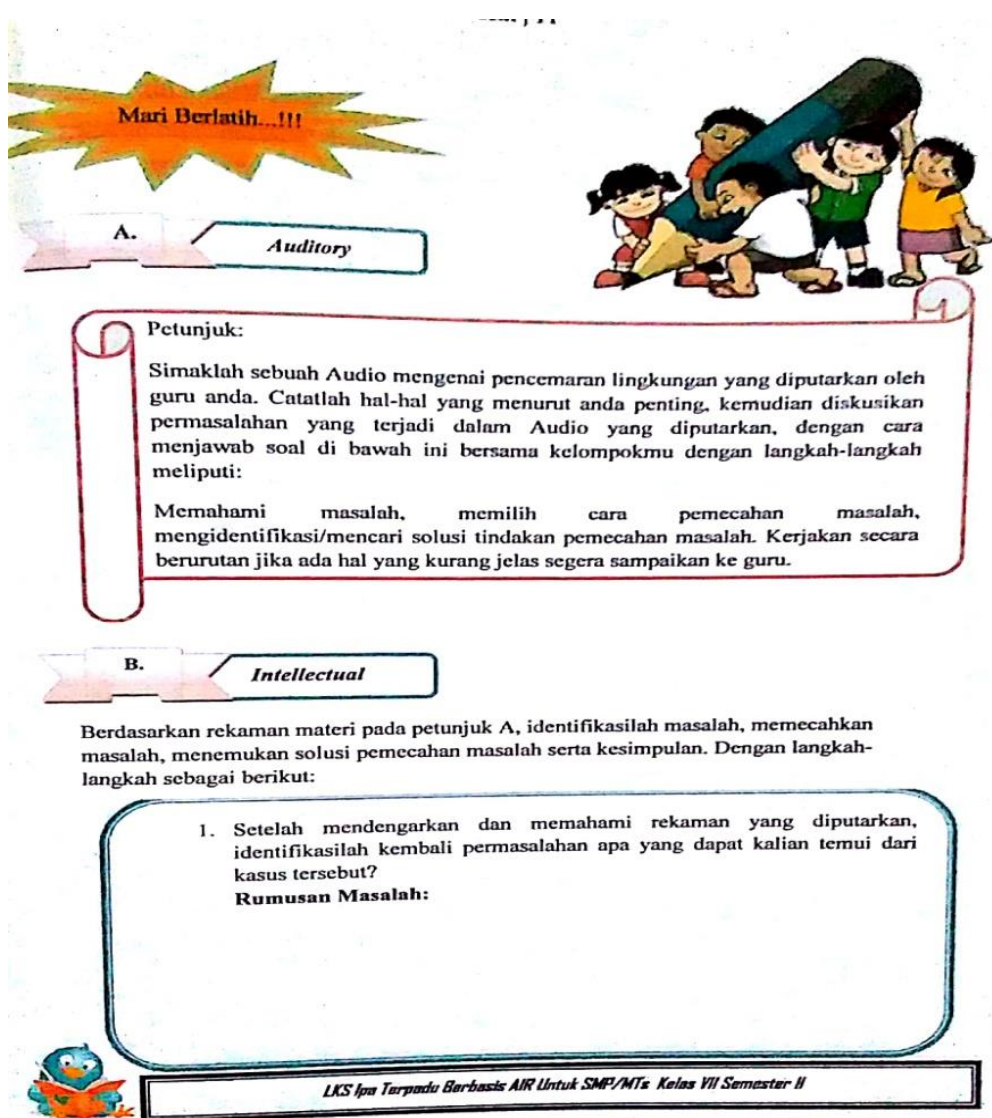

Gambar 5. Tampilan Tugas LKS Berbasis AIR

Kelebihan bahan ajar LKS berbasis Auditory Intellectually Repetition ini disusun berdasarkan langkah-langkah dalam model pembelajaran Auditory Intellectually Repetition, bahasa yang digunakan dalam LKS ini mudah untuk dipahami oleh siswa. LKS berbasis Auditory Intellectually Repetition ini dapat digunakan untuk menunjang proses belajar mengajar, serta dalam LKS ini juga bertujuan untuk merangsang siswa lebih aktif dalam berfikir tingkat tinggi untuk memecahkan suatu masalah yang telah disajikan sehingga dapat memberikan solusi dari masalah tersebut. Hal ini sejalan dengan pendapat dari Fitriyani (2013) mengenai kelebihan dari model pembelajaran Auditory Intellectually Repetition yaitu melatih pendengaran dan keberanian siswa untuk mengungkapkan pendapat (Auditory), melatih siswa untuk memecahkan masalah secara kreatif (Intellectually), dan melatih siswa untuk mengingat kembali tentang materi yang telah dipelajari (Repetition). Selain itu adanya beberapa Fitur tambahan di dalam LKS dapat menambah pengetahuan siswa mengenai dunia luar.

Untuk menghasilkan LKS yang layak digunakan maka terlebih dahulu dilakukan uji kelayakan LKS. Uji kelayakan LKS dilakukan oleh tiga dosen pendidikan biologi. Uji kelayakan dilakukan di kampus IKIP Mataram dengan 3 dosen ahli, ketiga dosen validator menilai komponen yang berbeda-beda secara berurutan yaitu mengenai isi, tampilan dan bahasa. Adapun hasil yang diperoleh dari validator isi yaitu 3,16, kemudian hasil dari validator tampilan sebesar 3,50 serta dari bahasa sebesar 3,70 maka nilai rerata dari ketiga validator adalah 3,28 sehingga LKS berbasis AIR ini dikatakan baik.

Setelah dilakukan uji kelayakan oleh dosen ahli serta perbaikan tampilan, kejelasan judul LKS, dan kesesuaian tujuan dengan indikator pembelajaran AIR, maka LKS berbasis AIR kemudian direvisi, dan dilakukanlah uji keterbacaan LKS. Uji keterbacaan ini dilakukan oleh siswa SMP kelas VII yang belum mendapatkan materi mengenai pencemaran lingkungan. Uji keterbacaan ini melibatkan 21 siswa kelas VII SMP Negeri 2 Gerung. Uji keterbacaan LKS dilakukan dengan cara membagikan LKS kepada siswa untuk dipelajari kemudian. Kemudian setelah siswa mempelajari LKS diberikanlah angket keterbacaan yang terdiri dari 8 aspek penilaian. Angket yang telah disebarkan kepada masing-masing siswa ini 
kemudian diisi sesuai dengan pendapat siswa mengenai LKS yang telah dibaca, dengan rentang skor 1 - 4.

Adapun skor rerata yang didapatkan dari hasil uji keterbacaan LKS terhadap siswa adalah 3,41 dengan kategori baik. Tiap aspek penilaian memiliki nilai yang beragam, nilai terendah terdapat pada aspek desain isi menarik dengan skor rata-rata yang diperoleh yaitu 2,90 dengan kategori cukup. Sedangkan skor rata-rata tertinggi didapatkan pada aspek ketiga yaitu mengenai jenis dan tampilan huruf sebesar 3,85 dengan kategori baik. Sementara itu secara berturut-turut nilai dari setiap aspek komponen penilaian yaitu desain cover menarik dan gambarnya menarik sebesar 3,38 , bahasa mudah di pahami sebesar 3,66 , urutan sajian runtut dan isinya mudah dipahami secara berturut yaitu 3,23 dan 3,28 sedangkan untuk aspek terakhir mengenai buku menarik minat belajar sebesar 3,61.

\section{KESIMPULAN}

Berdasarkan dari analisis data dan pembahasan hasil penelitian pengembangan LKS IPA Biologi berbasis AIR, maka dapat disimpulkan sebagai berikut, a) dihasilkan salah satu bahan ajar berupa LKS IPA Biologi berbasis AIR yang dapat dijadikan sebagai bahan ajar alternatif guru dan siswa SMP kelas VII pada materi pencemaran lingkungan. b) uji kelayakan pengembangan LKS IPA Biologi berbasis AIR dinyatakan layak dengan skor rata-rata validitas LKS sebanyak 3,28 sehingga dikategorikan baik. c) uji keterbacaan pengembangan LKS IPA Biologi berbasis AIR dinyatakan baik dengan skor rata-rata keterbacaan LKS sebanyak 3,41 sehingga dikategorikan baik.

\section{SARAN}

Berdasarkan penelitian yang telah dilakukan, maka saran yang dapat diberikan oleh peneliti yaitu sebagai berikut: (1) LKS berbasis AIR yang dihasilkan pada penelitian ini perlu didesiminasikan secara luas pada siswa dalam belajar di kelas. (2) Bagi peneliti lain yang berminat mengadakan penelitian mengenai model pembelajaran AIR lebih lanjut dapat menggunakan LKS ini sebagai bahan ajar untuk mengetahui kepraktisan serta keefektifan LKS.

\section{UCAPAN TERIMAKASIH}

Penelitian ini tidak menerima hibah khusus dari agensi pendanaan mana pun di sektor publik, komersial, atau nirlaba.

\section{DAFTAR PUSTAKA}

Burhan, A. V. Suherman, dan Mirna. (2014). Penerapan Model Pembelajaran Air pada Pembelajaran Matematika Siswa Kelas VIII SMPN 18 Padang. Padang: Jurnal Pendidikan Matematika Vol. 3 No. 1

Degeng, I.N.S. (2013). Ilmu Pembelajaran Klasifikasi Variabel untuk Pengembangan Teori Penelitian. Bandung: Kalam Hidup

Fitri, S. dan Utomo, R.B. (2016). Pengaruh Model Pembelajaran Auditory, Intellectually, and Repetition Terhadap Kemampuan Pemahaman Konsep di SMP Pustek Serpong. Tangerang; Jurnal e-DuMath Vol. 2 No. 2

Fitryani, F. (2013). Perbandingan Kemampuan Komunikasi Matematis Antara Siswa yang Mendapatkan Model Pembelajaran Auditory Intellectually Repetition (AIR) Dengan Snowball Throwing. (Skripsi STKIP Garut)

Hardiyanti.I.G.A., Wahyuni. D.S., Darmawiguna. I.G.M. (2013). Pengaruh Penggunaan Model Pembelajaran Auditory Intellectualy Repetition (AIR) Terhadap Hasil Belajar Siswa Kelas X. Bali; Kumpulan Artikel Mahasiswa Pendidikan Teknik Informatika (KARMAPATI) Vol. 2 No. 4

Kusumam, A. Dkk. (2016). Pengembangan Bahan Ajar Mata Pelajaran Dasar Dan Pengukuran Listrik Untuk Sekolah Menengah Kejuruan. Jurnal Pendidikan Teknologi dan Kejuruan, Vol. 23, No. 1

Prastowo, A. (2014). Pengembangan Bahan Ajar tematik. Cetakan ketujuh. Jakarta: Kencana. Suherman, E. (2003). Strategi Pembelajaran Matematika Kontemporer. Bandung: UPI 
Sukardi. (2016). Desain Model Prakarya Dan Kewirausahaan Berbasis Ekonomi Kreatif Berdimensi Industri Keunggulan Lokal. Mataram: Universitas Mataram.

Thiagarajan. Dkk. (1974). Instructional Development for Training Teachers of Exceptional Children: A Sourcebook. Washington, D. C.: National Center for Improvement of Educational Systems (DHEW/OE).

Widodo, C. dan Jasmadi. (2008). Buku Panduan Menyusun Bahan Ajar. Jakarta: PT Elex Media Komputindo. 